\title{
Assessement of control strategy by spraying low doses of sugars on apple orchard against Cydia pomonella (Linnaeus, 1758.)
}

\author{
Abd-el-Kader TIFFRENT ${ }^{1,2}$, Nadia LOMBARKIA ${ }^{1}$
}

\begin{abstract}
Assessement of control strategy by spraying low doses of sugars on apple orchard against Cydia pomonella (Linnaeus, 1758.)

Abstract: Codling moth (Cydia pomonella [L.]) is the most serious pest of apple worldwide. Its control still relies largely on insecticide applications. To deal with this situation, it becomes essential to design eco-friendly control systems to minimize chemical treatments. In this context, the effect of spraying of fructose (100 ppm), glucose (100 ppm) and insecticide (Deltamethrin), on the Golden Delicious variety against $C$. pomonella larval damages, was studied in an orchard located in Batna province (Algeria). The results of this study showed that codling moth own four generations in the study area. It is a very important pest with about $59.19 \pm 1.15 \%$ of damaged fruits at harvest. The spraying of glucose alone, fructose alone and the chemical insecticide alone causes a significant increase in the percentages of healthy fruit at harvest compared to the untreated control. The use of fructose and glucose has significantly reduced the percentage of damaged fruits at harvest followed by the spraying of the insecticide which produces the lowest percentage. The Abbott's efficacy of glucose treatments was 23.75 $\pm 2.6 \%$ compared to the insecticide $37.6 \pm 2.55 \%$; and fructose $15.54 \pm 3.01 \%$. The use of sugars is a completely innovative way in the field of plant protection. These first results demonstrate a promising alternative to conventional programs.

Key words: codling moth; glucose; fructose; Deltamethrin; 'Golden Delicious'
\end{abstract}

Received June 20, 2020; accepted December 10, 2020.

Delo je prispelo 20. junija 2020, sprejeto 10. decembra 2020.

Ocenitev nadzorovanja jabolčnega zavijača (Cydia pomonella (Linnaeus, 1758)) s škropljenjem z majhnimi odmerki sladkorjev

Izvleček: Jabolčni zavijač (Cydia pomonella [L., 1758]) je v svetovnem merilu najpomembnejši škodljivec jablan. Njegovo uravnavanje še vedno v največji meri temelji na uporabi insekticidov. Za odpravo tega je bistveno najti okolju prijazen način uravnavanja, ki bi zmanjšal obravnavanje s kemikalijami. V tem smislu je bil preučevan učinek škropljenja s fruktozo (100 ppm), glukozo (100 ppm) in insekticidom (Deltamethrin) na obseg poškodb zlatega delišesa (Golden Delicious) zaradi ličink jabolčnega zavijača v sadovnjaku, v provinci Batna, Alžirija. Rezultati so pokazali, da ima jabolčni zavijač na tem območju štiri generacije. Je zelo pomemben škodljivec, ki povzroči $59,19 \pm 1,15 \%$ poškodovanih plodov ob obiranju. Škropljenje samo z glukozo, fruktozo ali samo s kemijskim incekticidom je značilno povečalo odstotek zdravih plodov v primerjavi s kontrolo brez obravnavanj. Uporabi glukoze in fruktoze sta značilno zmanjšali odstotek poškodovanih plodov ob obiranju, a pri škropljenju z insekticidom je bil njihov odstotek najmanjši. Abbottove učinkovitosti obravnavanj so bile: $\mathrm{z}$ glukozo 23,75 $\pm 2.6 \%$, z insekticidom $37,6 \pm 2.55 \%$; in s fruktozo $1554 \pm$ $3,01 \%$. Uporaba sladkorjev je popolnoma nov način zaščite rastlin na prostem. Ti prvi izsledki nakazujejo obetajočo alternativo konvencionalnim programom zatiranja tega škodljivca.

Ključne besede: jabolčni zavijač; glukoza; fruktoza; Deltametrin; 'Golden Delicious'

1 ISVSA, University, Agronomy Department, Laboratory of Improvement of the Phytosanitary Protection Techniques in Mountanious Agrosystems, Algeria

2 Corresponding author, e-mail: abdelkader@univ-batna.dz 


\section{INTRODUCTION}

The economic impact of C. pomonella (L., 1758). (Lepidoptera; Tortricidae) on apple trees is continuously increasing. For reasons, the appearance of resistant populations to different insecticides (Charmillot et al., 2007). In addition to its high cost, insecticides present a potential danger to the environment and both the negative side effects on beneficials and occasionally resulting in outbreaks of secondary phytophagous pests. The concept of "Sweet Immunity" postulates that sugar metabolism and signalling influence plant immune networks (Tarkowski et al., 2019). Water-soluble metabolites (sugars and sugar-alcohols) have been already identified from surfaces of apple tree organs that they influence plant site acceptance after alighting and stimulate C. pomonella egg-laying (Derridj et al., 1999). Fructose, sorbitol, and myo-inositol are then especially concerned within a blend of six metabolites (Lombarkia \& Derridj, 2002).

Soluble carbohydrates and sugar-alcohols on the leaf surface should, however, provide information both about plant physiology and host plant specificity. The concept of exogenous application of sugars every 20 days on apple trees, to modify the egg-laying of $C$. pomonella to reduce the damage it causes, was tested in commercial orchards of several countries (in France, in Italy, in Greece and in Algeria) and over several years it showed an Abbott efficiency of 40 to $59 \%$ (Derridj et al., 2011).

The research hypothesis was that exogenous application of sugars on apple trees would provide satisfactory efficacy and treatments with fructose alone and glucose alone would have less fruit damages than the untreated control.

Codling moth larvae bore deep into the fruit making it unmarketable, it often leads to the fall of the fruit and may go through several generations in a growing season. However, it is often difficult to cope with large yield losses and the problem of reducing codling moth damage is therefore associated with challenges economic benefits for the study area.

Thus, the aim of the present paper is to evaluate the efficacy of sugars in reducing the damages caused by the codling moth.

\section{MATERIAL AND METHODS}

\subsection{STUDY SITE}

The experiment was performed in a 'Golden Delicious' apple orchard in the Batna region (eastern Algeria) $\left(35^{\circ} 21^{\prime} 12,4^{\prime \prime} \mathrm{N}, 006^{\circ} 01^{\prime} 19,1^{\prime \prime} \mathrm{E}\right)$ during 2019 with four different treatments against $C$. pomonella. The treated orchard was managed under common practices of the zone; it had a surface of 0.8 ha with 17 rows ( 19 trees each). The trees were 9 years old, and the plant spacing is $4 \mathrm{~m} \times 4$ $\mathrm{m}$, whereas the height of the trees is approximately $3 \mathrm{~m}$.

\subsection{SEXUAL TRAPPING OF ADULTS}

Attractive sex pheromone trap (produced and supplied by Russell IPM) was used to monitor the progress of flight (qualitative forecasting), follow the pest dynamics and to estimate the level of pest population of $C$. pomonella. The sexual trap consisted of a plate coated with glue, which was deposited on a capsule containing the specific pheromone ([E, E]-8, 10-dodecadien-1-ol), which attracts the males entering the delta trap and become trapped in the sticky area. The device was attached by a wire to the tree foliage, placed at eye level. The pheromone trap was installed between $17^{\text {th }}$ March and the harvest date $\left(25^{\text {th }}\right.$ September $)$, and it was replaced at 6 weeks intervals. The observations were carried out every 3 days for 6 months (from March until September 2019). For each output, the date of catches and the total number of captured moths were mentioned.

\subsection{TREATMENTS}

The treatments were adjusted in a randomized Latin square with 4 repetitions. All the modalities (4) are then distributed within each of the four blocks and each block has 3 trees. The efficacy was measured by the extent to which fruit damage attributable to C. pomonella caterpillars was reduced by each treatment, compared to the unsprayed control. The applications were performed using electrical pressure sprayer (12 V-12 Ah), capacity of

Table 1: Tested Modalities and their doses

\begin{tabular}{|c|c|c|}
\hline Modalities & Doses & Treatments \\
\hline 1 & Control (Untreated) & Control (Untreated) \\
\hline 2 & Fructose (Fluka Biochemika) & 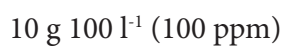 \\
\hline 3 & Glucose (Fluka Biochemika) & 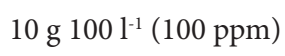 \\
\hline 4 & Decis 25 EC containing 25g 1-1 Deltamethrin (Bayer) & (0.5 l) $1000 \mathrm{l}^{-1}$ \\
\hline
\end{tabular}


161. The modalities tested and their doses are reported in Table 1 .

The morning treatments (sugars and insecticide) were carried out every 20 days throughout the season from the flowering end until harvest (Derridj et al., 2012).

\subsection{DAMAGE ASSESSMENTS}

The variable 'percentage of infested and healthy fruits at harvest' is based on the ratio of the total number of infested fruits (damaged) and the total number of healthy fruits per plot. Abbott's formula is very commonly used in field trials. Its efficacy at harvest measures the percentage of $C$. pomonella caterpillars infested fruits versus untreated controls according to the formula $\mathrm{T} 0-\mathrm{Tt} / \mathrm{T} 0 \times 100$; where $\mathrm{T} 0$ is the percentage of infested fruits in the untreated plots and $\mathrm{Tt}$ is the percentage of infested fruits in the treated plots.

\subsection{STATISTICAL ANALYSIS}

The means between each variable 'percentage of infested fruits, healthy fruits at harvest', and Abbott's efficacy for the four modalities were compared by ANOVA on ranks test, followed by post hoc analysis using Fisher's and Tukey's tests (Table 3). A p-value of 0.05 was used to establish significance in all tests. All analyses were performed using SPSS software v. 2016.

\section{RESULTS AND DISCUSSION}

\subsection{SEXUAL TRAPPING OF ADULTS}

Considering the entire trapping season, 708 males were captured between March 20 and September 25, the captures per trap per three days varied between 1 and 73, that is on average 25.82 males /trap/week. The pace of the annual flight is shown quad-modal with the first tip of 32 males on April 22, and the second of 73 individuals from July 03, the third of 22 individuals on August 20 and the fourth 18 individuals on September 10 (Figure 1). The gates of the developed generations would then present the following sequences, the first (14.26\% of annual catches) taked place between March 20 (milestone date of the start of the insect's activity) and May first. The second has a significant importance of $56.35 \%$, from May 4 to July 18 . The third (15.96 \%) took place between July 21 and August 26. The fourth, scanty (13.41\%) due to diapauses, fully covered the month of September (Table 2).

The determination of generations is based on the following principle: the division a significant and stable increase in catches, followed by a sufficiently long inter-flight ( \pm 30 days) with few catches, indicates a nascent or finishing flight comparable to the start or the end of a generation (Hmimna \& El Iraqui, 2015).

\subsection{DAMAGE ASSESSMENTS AND TREATMENTS EFFICACY}

The spraying of glucose alone, fructose alone and the insecticide induced a significant increase in the percentages of healthy fruit at harvest compared to the untreated control. The analysis of variance (ANOVA) followed by the Tukey test $(p<0.05)$ identified three groups, control (40.80\%, group a), glucose and fructose $55.03 \%$, $50.29 \%$ respectively (group b) and insecticide $63.19 \%$ (group c) (Table 3).

Similarly, foliar sprays of fructose and glucose made it possible to significantly reduce the percentage of fruit

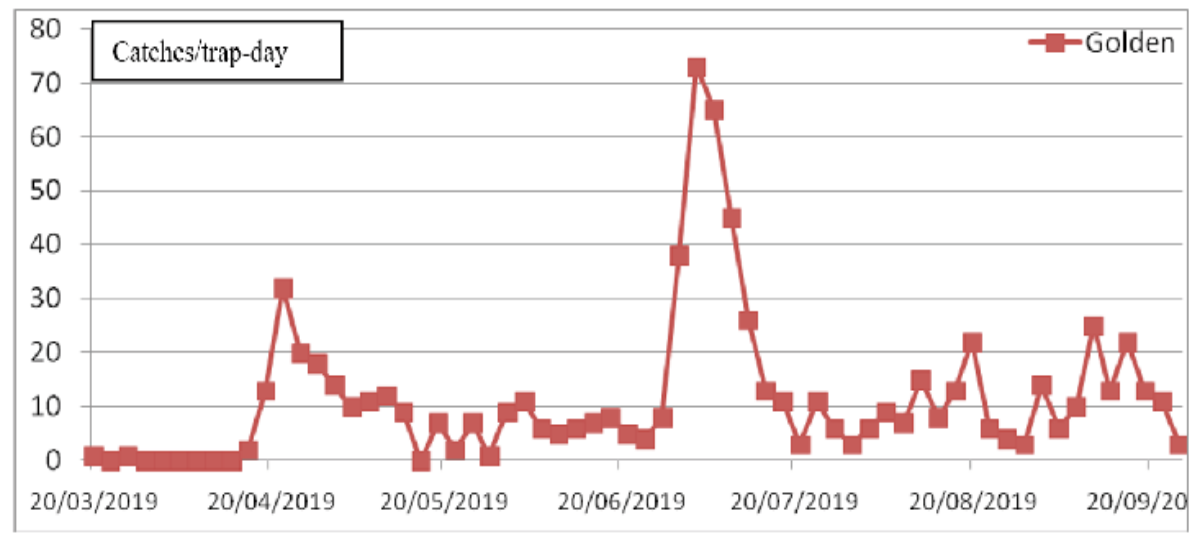

Figure 1: Seasonal flights of adult males of C. pomonella in ‘Golden Delicious' orchard 
Table 2: The number of catches and their percentage of C. pomonella during the four generations

\begin{tabular}{lllll}
\hline Generations & G1 & G2 & G3 & G4 \\
\hline Total number of catches & 101 & 399 & 113 & 95 \\
$\%$ of catches & $14.26 \%$ & $56.35 \%$ & $15.96 \%$ & $13.41 \%$ \\
\hline
\end{tabular}

damaged at harvest compared to the control, the analysis of variance (ANOVA) followed by the Tukey test ( $p<$ $0.05)$ revealed three groups, control (59.19\%, group a), glucose and fructose $44.96 \%$ and $49.70 \%$ respectively (group b), followed by the spraying of the insecticide which produces the lowest percentage of $36.80 \%$ (group c), (Table 3).

The Abbott's efficiency of glucose treatments is $23.75 \%$ compared to the insecticide with $37.6 \%$ and fructose generating an average percentage efficiency of $15.54 \%$ (Table 3).

Previous studies in Algeria and in France from 2009 to 2014 summarized by Arnault et al. (2016) have demonstrated the potential of foliar application of sucrose in micro-doses to control C. pomonella, and revealed a degree of infested fruits at harvest of the untreated control varied from 12 to $46.8 \%$ in nine experiments were conducted in apple orchards. Compared with this study, the infestation was more important with $59.19 \%$ at harvest which represent a very high pressure of the pest.

The mentioned studies showed that sucrose can induce partial resistance to $C$. pomonella by foliar applications at a very low dose of $0.01 \%$. The mean Abbott's efficacy obtained for sucrose $100 \mathrm{ppm}$ alone was $41.0 \pm$ $10.0 \%$, while sucrose in combination with thiacloprid insecticide; enhanced the efficacy of thiacloprid treatment by $18 \%$. The researchers have concluded that the effect of this combination is not additive but synergistic and rather potentiating.

Furthermore, Arnault et al. (2015) confirmed, in their study conducted in an integrated fruit protection orchard on the Granny Smith variety, the advantage of applying fructose $100 \mathrm{ppm}$ in combination with OrganoPhosphorus OP or Insect Growth Regulator (IGR) insecticides against codling moth. Sprays of fructose at
$100 \mathrm{ppm}$ in combination with OP and IGR have significantly reduced the percentage of damaged fruits at harvest compared to the OP and IGR alone $(6.5 \%$ and $10 \%$ respectively); efficiency was therefore improved by $35 \%$ when fructose combined with OP and IGR. The same author has specified that in studies leading during 2013 and 2014 in an organic orchards, the foliar applications of fructose at $100 \mathrm{ppm}$ could reduce codling moth damage by $55 \%$ on the Gala variety, knowing that the use of fructose at $100 \mathrm{ppm}$ has significantly reduced the percentage of damaged fruits at harvest compared to the control $(3,6$ $\%, 14,9 \%)$ and $(2,5 \%, 3,9 \%)$ respectively, and the Abbott effectiveness was $76 \%$ (in 2013) and $36 \%$ in 2014). These researches are in good agreement with the results of the present study; this is consistent that the exogenous foliar application of a single sugar can induce plant resistance to the pest. Derridj et al. (2012) argued that foliar application of sucrose alone and/or other compounds from the formulation such as sugars are introduced into the commercial granulovirus products as phago-stimulants for more effective ingestion by larvae can induced modification of the cuticular permeability and, therefore, of the composition of the leaf surface blend and its effects on pest behavior. Burges and Jones (1998) presented the sugars advantages in the formulation of microbial biopesticides; act as phagostimulants, preservatives and dispersants.

It was the main purpose of the paper to draw attention to primary metabolites, in particular, soluble carbohydrates. The sugars applied on the leaves in the morning (best diffusion through the cuticle while the apoplast concentrations are low) are those usually found on apple leaves in the evening. This knowledge of sweet immunity here is even more complex. It seems to be resulted from an induction of partial antixenosis at the $C$. pomonella

Table 3: Percentage of damaged and healthy fruits in apple orchards $(\mathrm{n}=12)$ on different modalities (control, fructose, glucose, insecticides)

\begin{tabular}{llll}
\hline Treatments & $\begin{array}{l}\text { \% damaged fruits } \\
\left(\text { Mean }+\mathrm{SEM}^{*}\right)\end{array}$ & $\begin{array}{l}\text { \% healthy fruits } \\
\left(\text { Mean }+\mathrm{SEM}^{*}\right)\end{array}$ & $\begin{array}{l}\text { \% Abbott effectiveness } \\
\left(\text { Mean }+\mathrm{SEM}^{*}\right)\end{array}$ \\
\hline Control (Untreated) & $59,19 \pm 1,15 \mathrm{a}$ & $40,80 \pm 1,15 \mathrm{a}$ & $15,54 \pm 3,0 \mathrm{a}$ \\
fructose $100 \mathrm{ppm}$ & $49,70 \pm 1,20 \mathrm{~b}$ & $50,29 \pm 1,19 \mathrm{~b}$ & $23,75 \pm 2,6 \mathrm{a}$ \\
glucose $100 \mathrm{ppm}$ & $44,96 \pm 1,34 \mathrm{~b}$ & $55,03 \pm 1,33 \mathrm{~b}$ & $37,60 \pm 2,55 \mathrm{~b}$ \\
Insecticide (Deltamethrin) & $36,80 \pm 1,40 \mathrm{c}$ & $63,19 \pm 1,39 \mathrm{c}$ & \\
\hline
\end{tabular}

* Values indicated with different letters are significantly different at $\mathrm{p}<0.05$ 
egg-laying linked to changes in chemical signals of the leaf surface induced by applications of these sugars, confirmed by the findings of Lombarkia (2002) and Lombarkia and Derridj (2008) that have been clearly investigated the important role of primary metabolites and particularly sugars on C. pomonella. Egg-laying site preference within the apple tree and its intensity is related to a blend of three soluble carbohydrates (sucrose, D-fructose, and glucose) and three sugar alcohols (sorbitol, quebrachitol, myo-inositol) present at the surface of the apple tree. Quantities and ratios of the six primary metabolites found on the leaf surface may influence host preference of C. pomonella as well as their egg-laying behavior, thus they may play a role in the trees' resistance to the codling moth (Lombarkia \& Derridj, 2008).

On the other hand, the resistance effect on C. pomonella female egg-laying is predominant in the reduction of larval damage, but this does not exclude effects on the neonate larvae before penetrating into the fruit. Derridj et al. (1999) found that soluble carbohydrates and sugaralcohols present on apple tree surface discriminates apple tree sites such as leaves and leaf side, among the present substances, six were studied in laboratory in their study, fructose, sorbitol and myo-inositol stimulate C. pomonella egg-laying and enhance examination of the support by the neonate larvae. Glucose showed more deterrent effect on females and larvae, whereas quebrachitol and myo-inositol arrested neonate larvae at the highest concentrations. In addition, we know that in the formulation of microbial biopesticides, there are simple sugars used for many reasons. It is probable that sugar has physiological effects on the plant. Stacey et al. (1977, 1980), suggested that increases in cotton yield recorded in the presence of sugars may have been due to the physiological effects of the sugar on the plant. Also, sucrose is routinely used with $B$. thuringiensis Berliner 1915 on grape against grape berry moth.

\section{CONCLUSIONS}

Based on our results, it can be concluded that small molecules such as glucose and fructose can induce partial resistance to C. pomonella by foliar applications. This study should stimulate research on this concept for the development of eco-friendly control strategies.

I recommended conducting future researches on the effect of foliar applications of sugars on C. pomonella egglaying and its oviposition site selection.

\section{REFERENCES}

Arnault I., Bardin M., Ondet S., Furet A., Chovelon M.,
Kasprick A. C., Marchand P., Clerc H., Davy M., Roy G., Romet L., Auger J., Mançois A. , Derridj S. (2015). Utilisation de micro-doses de sucres en protection des plantes. Innovations Agronomiques, 46, 1-10.

Arnault I., Lombarkia N., Joy-Ondet S., Romet L., Brahim I., Meradi R., Nasri A., Augere J., Derridj S. (2016). Foliar application of microdoses of sucrose to reduce codling moth Cydia pomonella L. (Lepidoptera: Tortricidae) damage to apple trees. Pest Management Science, 72, 1901-1909. https://doi.org/10.1002/ps.4228

Burges H. D. \& Jones K. A. (1998). Formulation of Microbial Biopesticides: Beneficial Microorganisms, nematodes and seed treatments, (Ed.), Kluwer Academic Publishers, Springer Science+Business Media Dortrecht, p. 411. https://doi. org/10.1007/978-94-011-4926-6

Charmillot P. J., Pasquier D., Salamin C. H., Briand F.,Ter-Hovannesyan A., Azizian A., Kutinkova H., Peeva P., Velcheva N. (2007). Détection de la résistance du carpocapse Cydia pomonella, Tests d'insecticides sur des chenilles diapausantes de Suisse, d'Arménie et de Bulgarie. Revue suisse Viticulture Arboriculture Horticulture, 39(6), 385-389.

Derridj S., Cabanat I., Cochet E., Couzi P., Lombarkia N., Wu B. R. (1999). Incidence des métabolites présents à la surface des organes du pommier sur le comportement de Cydia pomonella (Lepidoptera, Tortricidae); A.N.P.P. 5ème Conférence Internationale sur les Ravageurs en Agriculture. Montpellier, 7-9 December, pp. 279-286.

Derridj S., Arnault I., Nicholas A., Birch E., Elad Y., Lombarkia N., Couzi P., Pierre P. Auge J. (2011). Les sucres solubles, une opportunité pour l'agriculture durable. Phytoma- la défense des plantes, 640, 10-14.

Derridj S., Lombarkia N., Garrec J. P., Galy H. and Ferré E. (2012). Sugars on leaf surfaces used as signals by the insect and the plant: implications in orchard protection against Cydia pomonella L. (Lepidoptera, Tortricidae). In: Moths: Types, Ecological Significance and Control, ed. by Cauterrucio L. Nova Science Publishers Inc., Hauppage, NY, pp. $1-38$

Hmimina M., \& El Iraqui S. (2015). Cycle évolutif et voltinisme du Carpocapse (Cydia pomonella L., Lepidoptera, Tortricidae) exprimés par le piégeage sexuel et les degrés-jours dans la région d'Azrou. [Life cycle and voltinism of codling moth (Cydia pomonella L., Lepidoptera, Tortricidae) based on sexual trapping and degree days in Azrou region]. Revue Marocaine des Sciences Agronomiques et Vétérinaires, 3(2), 1.

Lombarkia N. (2002). Influence de métabolites présents à la surface des organes du pommier sur la ponte du carpocapse: Cydia pomonella L. (Lepidoptera: Tortricidae). Application à l'étude de la résistance du pommier au ravageur. Doctoral dessertation. Université Rennes 1, France.

Lombarkia N., \& Derridj S. (2002). Incidence of apple and leaf surface metabolites on Cydia pomonella oviposition. Entomologia Experimentalis et Applicata, 104, 79-87. https:// doi.org/10.1046/j.1570-7458.2002.00993.x

Lombarkia N., \& Derridj S. (2008). Resistance of apple trees to Cydia pomonella egg-laying due to leaf surface metabolites. Entomologia Experimentalis et Applicata, 128, 57-65. https://doi.org/10.1111/j.1570-7458.2008.00741.x 
Stacey A. L., Yearian W. C., Young S. Y. (1977). Evaluation of Baculovirus heliothis with feeding stimulants for control of heliothis larvae on cotton. Journal of Economic Entomology, 70, 779-84. https://doi.org/10.1093/jee/70.6.779

Stacey A. L., Luttel R., Yearian, W. C. (1980). Field evaluation of Baculovirus heliothis on cotton using selected application methods. In: Burges H.D., \& Jones K.A. Formulation of Microbial Biopesticides: Benefecial Microorganisms, nematodes and seed treatments, (Ed.), Kluwer Academic Publishers, Springer Science+Business Media Dortrecht, p. 411.

Tarkowski L. P., Poel B. V., Höfte M., Ende W. V. (2019). Sweet Immunity: Inulin Boosts Resistance of Lettuce (Lactuca sativa) against Grey Mold (Botrytis cinerea) in an EthyleneDependent Manner, International Journal of. Molecular. Sciences, 20, 1052. https://doi.org/10.3390/ijms20051052 